\title{
R Plasmids which Alter Ultraviolet Light-sensitivity and Enhance Ultraviolet Light-induced Mutability in Pseudomonas aeruginosa
}

\author{
By P. R. LEHRBACH, A. H. C. KUNG AND B. T. O. LEE \\ Department of Genetics, University of Melbourne, Parkville, Victoria 3052, Australia
}

(Received 18 April 1978)

\begin{abstract}
R plasmids pMG1, R2, R931 and pMG15 increased the survival of Pseudomonas aeruginosa exposed to ultraviolet radiation (u.v.) in the wild type, and $u v r$ and pol $A$ mutants but did not alter the u.v.-response of a rec $A$ mutant. The $\mathrm{R}$ plasmid RPL11 reduced u.v.-survival in the wild type, and $u v r$ and polA mutants but did not alter the u.v.-response of a $r e c A$ host. All the plasmids enhanced the level of spontaneous and u.v.-induced back mutation $\left(\operatorname{Trp}^{+}\right)$in a $\operatorname{trpB1}$ strain.

The effect of a sublethal concentration of sodium arsenite following u.v.-irradiation was

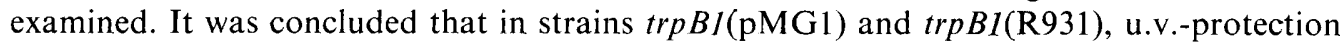
is determined by a $r e c A^{+}$-dependent, arsenite-sensitive repair pathway, whereas in strains $\operatorname{trp} B 1(\mathrm{R} 2)$ and $\operatorname{trp} B l(\mathrm{pMG} 15)$, u.v.-protection is determined by a $\operatorname{rec} A^{+}$-dependent, arsenite-insensitive step in DNA repair.
\end{abstract}

\section{INTRODUCTION}

Certain R plasmids of Pseudomonas aeruginosa (Krishnapillai, 1975; Lehrbach et al., 1977 a) alter the ultraviolet light (u.v.) sensitivity of host bacteria and increase their susceptibility to the mutagenic effects of u.v. light. These properties suggest that the plasmids may contribute to some step or steps involved in the DNA repair pathways of $P$. aeruginosa. Analysis of the u.v.-protective plasmid pMG2 (Lehrbach et al., 1977a) suggests that a plasmid-determined repair resynthesis function may be responsible for increased u.v.survival and enhanced u.v.-mutability of bacteria containing pMG2.

In this study we report the effects on u.v.-survival and u.v.-mutagenesis of several independently isolated $\mathrm{R}$ plasmids which alter the u.v.-sensitivity of wild-type host bacteria (G. A. Jacoby, personal communication). We have previously suggested that an arsenitesensitive, rec $A^{+}$-dependent step in DNA repair may be responsible for u.v.-protection and enhanced u.v.-induced mutability by the R plasmid pMG2 (Lehrbach et al., 1977b). The effect of a sublethal concentration of sodium arsenite on u.v.-survival is reported for the $\mathrm{R}$ plasmids used in this study.

\section{METHODS}

Bacteria. The R plasmids used are described in Table 1; the bacterial strains were described previously (Lehrbach et al., 1977a,b). The trp allele $(\operatorname{trpBI})$ is designated according to the nomenclature used by Crawford (1975) (formerly trpF1; Calhoun et al., 1973).

General culture conditions and transfer of $R$ plasmids. These techniques have been previously described (Kung \& Lee, 1973; Lehrbach et al., 1977a). Antibiotics were added at the following concentrations $\left(\mu \mathrm{g} \mathrm{ml}^{-1}\right)$ : gentamicin, 20; streptomycin, 200; carbenicillin, 500; tetracycline, 250.

Measurement of u.v. survival and u.v. mutagenesis. These techniques were described by Kung \& Lee (1973) and Lehrbach et al. $(1977 \mathrm{~b})$. Three plates were used to determine the spontaneous levels of back mutation $\left(\operatorname{Trp}^{+}\right)$. The minimum number of revertants scored per plate was 30 before calculations were made of both the spontaneous and induced frequencies of back mutation. 


\begin{tabular}{|c|c|c|c|c|}
\hline Plasmid & $\begin{array}{l}\text { Incom- } \\
\text { patibility } \\
\text { group }\end{array}$ & Resistance pattern* & Plasmid origin & Reference \\
\hline pMG1 & P-2 & Gm Sm Su Hg UV & South Africa & Jacoby (1974) \\
\hline R931 & P-2 & Sm Tc Hg UV & Canada & Tseng \& Bryan (1973) \\
\hline RPL11 & P-2 & $\mathrm{Cb} \mathrm{Cm} \mathrm{Gm} \mathrm{Sm} \mathrm{Su} \mathrm{Tc} \mathrm{Hg}$ & U.S.A. & Korfhagen \& Loper (1975) \\
\hline pMG15 & $?$ & $\mathrm{Hg} \mathrm{UV}$ & Ireland & $\begin{array}{l}\text { Falkiner } \text { et al. (1977) } \\
\text { Jacoby (personal communication) }\end{array}$ \\
\hline R2 & P-9 & Cb Sm Su UV & Japan & Kawakami et al. (1972) \\
\hline
\end{tabular}

* Antibiotic resistances: $\mathrm{Cb}$, carbenicillin; $\mathrm{Cm}$, chloramphenicol; $\mathrm{Gm}$, gentamicin; Sm, streptomycin; $\mathrm{Su}$, sulphonamide; Tc, tetracycline. $\mathrm{Hg}$, Resistance to mercuric ions. UV, U.v.-protection or resistance.

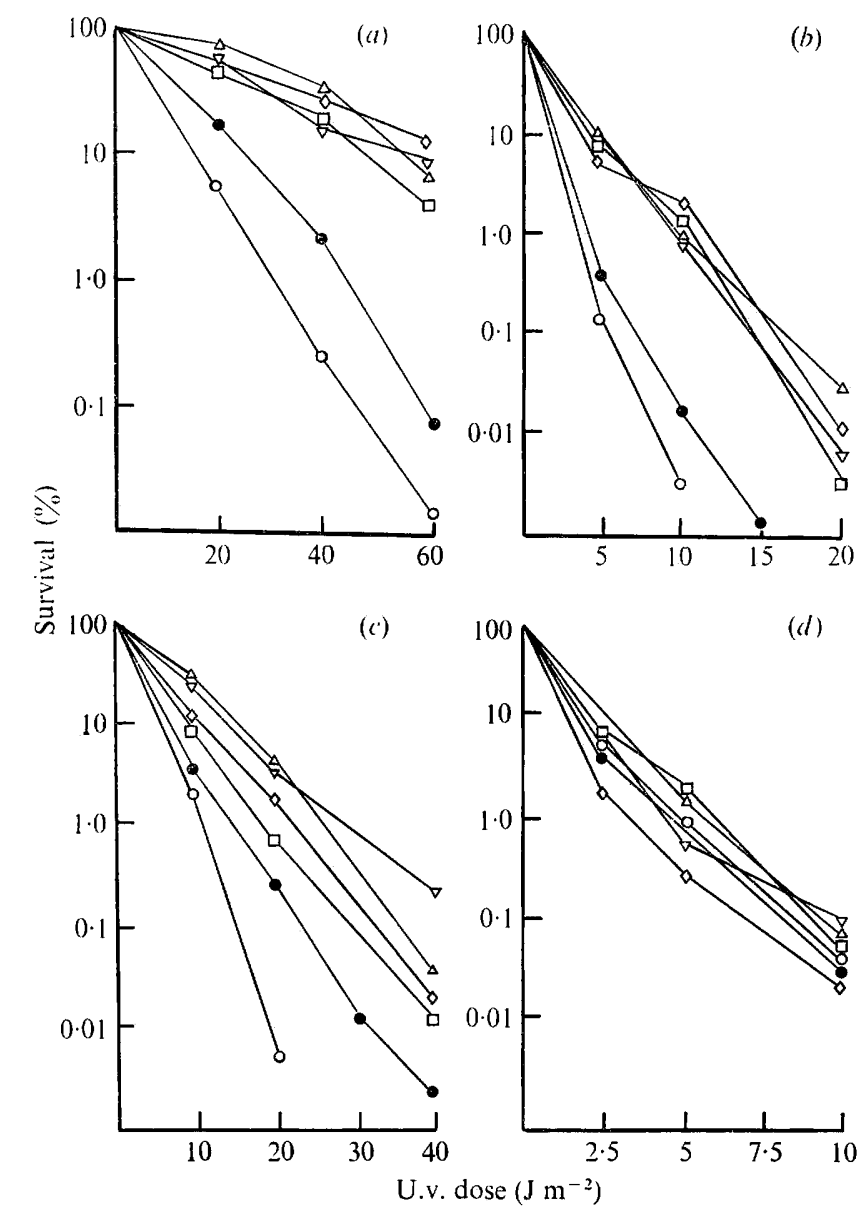

Fig. 1. U.v.-survival curves of strains (a) PAO1, $(b)$ GMA918, (c) GMB112 and $(d)$ PAO2003, without plasmids $(\bullet)$ or with R plasmids pMG1 $(\square)$, R931 $(\nabla), \mathrm{R} 2(\triangle)$, pMG15 $(\diamond)$ or RPL11 $(\bigcirc)$.

\section{RESULTS AND DISCUSSION}

U.v.-survival curves for the wild-type strain (PAO1) and three u.v.-radiation-sensitive mutants with and without the $\mathrm{R}$ plasmids are shown in Fig. 1. These strains were selected to define, as far as possible in this organism, the major repair pathways: they were GMA918, a $u v r$-type mutant (Kung \& Lee, 1973); GMB112, a polA-type mutant (Lehrbach et al., 1976); and PAO2003, a recA-type mutant (Chandler \& Krishnapillai, 1974). The R plasmids pMG1, 
Table 2. U.v.-induction of $\operatorname{Tr}^{+}$revertants in strains $\operatorname{trpB1}, \operatorname{trpB1}(\mathrm{pMG} 1), \operatorname{trp} B 1(\mathrm{R} 931)$, $\operatorname{trp} B 1(\mathrm{R} 2), \operatorname{trp} B 1(\mathrm{pMG} 15)$ and $\operatorname{trp} B 1(\mathrm{RPL} 11)$

\begin{tabular}{|c|c|c|c|c|}
\hline \multirow[b]{2}{*}{ Strain } & \multirow{2}{*}{$\begin{array}{l}\text { Spontaneous } \\
\text { frequency } \\
\text { per } 10^{7} \text { cells } \\
\text { plated }\end{array}$} & \multicolumn{3}{|c|}{$\begin{array}{l}\text { Induced frequency per } 10^{7} \text { survivors* } \\
\text { at u.v. dose }\left(\mathrm{J} \mathrm{m}^{-2}\right) \text { : }\end{array}$} \\
\hline & & 5 & 10 & 20 \\
\hline $\operatorname{trp} B 1$ & 3 & $\begin{array}{c}3 \\
(58)\end{array}$ & $\begin{array}{c}7 \\
(21)\end{array}$ & $\begin{array}{c}14 \\
(4 \cdot 5)\end{array}$ \\
\hline 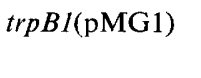 & 7 & $\begin{array}{c}79 \\
(87)\end{array}$ & $\begin{array}{r}134 \\
(86)\end{array}$ & $\begin{array}{l}204 \\
(65)\end{array}$ \\
\hline $\operatorname{trp} B 1$ (R931) & 9 & $\begin{array}{c}56 \\
(85)\end{array}$ & $\begin{array}{c}92 \\
(68)\end{array}$ & $\begin{array}{r}193 \\
(62)\end{array}$ \\
\hline $\operatorname{trp} B I(\mathrm{R} 2)$ & 9 & $\begin{array}{c}38 \\
(85)\end{array}$ & $\begin{array}{c}73 \\
(70)\end{array}$ & $\begin{array}{r}123 \\
(50)\end{array}$ \\
\hline $\operatorname{trp} B I(\mathrm{pMG15})$ & 15 & $\begin{array}{c}36 \\
(65)\end{array}$ & $\begin{array}{c}55 \\
(60)\end{array}$ & $\begin{array}{l}120 \\
(38)\end{array}$ \\
\hline $\operatorname{trpBI(RPL11)}$ & 11 & $\begin{array}{l}54 \\
(57)\end{array}$ & $\begin{array}{c}95 \\
(13)\end{array}$ & $\begin{array}{c}-\dagger \\
(0 \cdot 6)\end{array}$ \\
\hline
\end{tabular}

* Numbers show the mean frequency of $\operatorname{Trp}^{+}$revertants per $10^{7}$ survivors, corrected for spontaneous mutations by subtracting the mean frequency of revertants on the non-irradiated plates (Lehrbach et al., $1977 \mathrm{~b}$ ); numbers in parentheses show the percentage survival.

$\dagger$ Mean frequency of $\mathrm{Trp}^{+}$revertants appearing on irradiated plates was less than the mean frequency of revertants on the non-irradiated plates.

R931, R2 and pMG15 protected $P$. aeruginosa against the lethal effects of u.v. light in the wild-type strain, the $u v r$-type mutant and the polA-type mutant, but had no protective effect in the $r e c A$-type strain. A $r e c A^{+}$gene product is therefore necessary for the expression of the u.v.-protective effect of these plasmids. This suggests that the plasmids' gene product(s) contribute to the $r e c A^{+}$-dependent repair of u.v.-damaged host DNA.

The R plasmid RPL11, on the other hand, reduced survival of the wild-type, and the $u v r$-type and the polA-type mutants following u.v.-irradiation but did not alter the u.v.sensitivity of the rec $A$-type mutant. The sensitizing effect of RPL11 is thus also dependent on an intact $r e c A^{+}$gene product.

Since error-prone repair processes are dependent on an intact $\mathrm{recA}^{+}$gene in Escherichia coli (Witkin, 1976), it was of interest to determine whether these $\mathrm{R}$ plasmids had an effect on the yields of u.v.-induced mutations in $P$. aeruginosa. The $\mathrm{R}$ plasmids were transferred into the tryptophan auxotroph $\operatorname{trpB1}$ (Crawford, 1975). Back mutation to prototrophy (Trpto $\operatorname{Trp}^{+}$) was calculated following exposure to various u.v. doses (Table 2). U.v.-induced back mutation was substantially increased with the 'u.v.-protecting' plasmids pMG1, R931, R2 and pMG15. With the R plasmid RPL11, which reduced the survival of strain $\operatorname{trpB1}$, a significant increase in u.v.-induced back mutation was observed at low doses. All the plasmids tested increased the spontaneous back mutation rate of strain $\operatorname{trp} B 1$ (Table 2).

The u.v.-protective effect of pMG1, R931, R2 and pMG15 is dependent on the rec $A^{+}$ gene of $P$. aeruginosa since these plasmids did not alter the u.v.-survival of a rec $A$-type mutant of $P$. aeruginosa. Since studies using $E$. coli B have shown that sodium arsenite inhibits a rec $A^{+}$-dependent step in the repair of u.v.-irradiated DNA (Rossman et al., 1975), the effect of a sublethal concentration of sodium arsenite $(1 \mathrm{mM})$ in the plating medium following u.v.-irradiation was examined in strain $\operatorname{trp} B I$ containing $\mathrm{R}$ plasmids. This would indicate whether arsenite-sensitive or arsenite-insensitive repair pathways were involved in the u.v.-protective effect of these $\mathbf{R}$ plasmids. The presence of sodium arsenite eliminated the increased u.v.-survival of $\operatorname{trpB1}(\mathrm{pMG})$ and $\operatorname{trp} B 1(\mathrm{R} 931)$ reducing the survival to that of u.v.-irradiated strain $\operatorname{trpBl}$ in the presence of sodium arsenite (Fig. $2 a$ ). This effect was

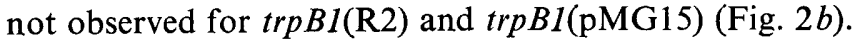




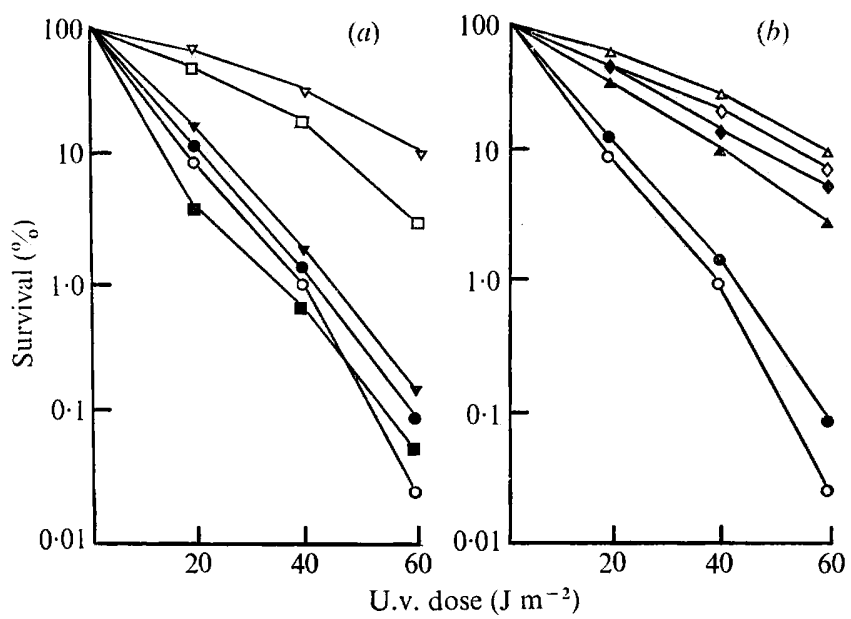

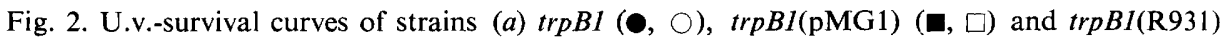
$(\nabla, \nabla)$ and $(b) \operatorname{trp} B 1(\bullet, \bigcirc), \operatorname{trp} B 1(\mathrm{R} 2)(\triangle, \triangle)$ and $\operatorname{trp} B 1(\mathrm{pMG} 15)(\diamond, \diamond)$, in the presence (filled symbols) or absence (open symbols) of 1 mM-sodium arsenite.

Although the u.v.-survival of strain $\operatorname{trp} B 1$ was not significantly affected by the presence of sodium arsenite (unlike E. coli В; Rossman et al., 1975), sodium arsenite has been shown to inhibit a $\mathrm{recA} \mathrm{A}^{+}$-dependent function which may be responsible for u.v.-protection and enhanced u.v.-mutagensis by the Pseudomonas R plasmid pMG2 (Lehrbach et al., 1977b). From these studies the mechanism of action of sodium arsenite is not clear, although further studies in $E$. coli B have shown that the induction of RNA synthesis is the function most sensitive to arsenite inhibition (Rossman et al., 1977). Thus rec $A^{+}$-dependent functions that require de novo protein synthesis for their involvement in repair processes would more likely be affected by the presence of a sublethal concentration of sodium arsenite. The response of the various $\mathrm{R}$ plasmids tested in this study to sodium arsenite following u.v.irradiation indicates that the ability of the P-2 group plasmids R931, pMG1 (and pMG2; Lehrbach et al., 1977b) to give enhanced survival of host cells after u.v.-irradiation is determined by a plasmid gene product(s) which participates in a $\operatorname{rec} \mathrm{A}^{+}$-dependent, errorprone, arsenite-sensitive pathway of $P$. aeruginosa. However, the R plasmids R2 and pMG15, which are not greatly affected by the presence of sodium arsenite in their protection of host cells against u.v.-damage, may be involved in an arsenite-insensitive step in DNA repair of $P$. aeruginosa, which is also error-prone and $r e c A^{+}$-dependent.

These results, together with the observed ability of the R plasmid RPL11 to increase the u.v.-sensitivity of a wild-type host cell and yet enhance the level of u.v.-induced back mutation in strain $\operatorname{trp} B I$, indicate that several mechanisms or gene products may be responsible for these plasmid-mediated alterations in response to u.v.-irradiation.

This work was supported by a Research and Training Grant from the Australian Institute of Nuclear Science and Engineering.

\section{REFERENCES}

Calmoun, D. H., Pierson, D. L. \& Jensen, R. A. (1973). The regulation of tryptophan biosynthesis in Pseudomonas aeruginosa. Molecular and General Genetics 121, 117-132.

Chandler, P. M. \& Krishnapillai, V. (1974). Isolation and properties of recombinationdeficient mutants of Pseudomonas aeruginosa. Mutation Research 23, 15-23.

CRAWFORD, I. P. (1975). Gene rearrangements in the evolution of the tryptophan synthetic pathway. Bacteriological Reviews 39, 87-120.

Falkiner, F. R., Keane, C. T., Dalton, M., Clancy, M. T. \& Jacoby, G. A. (1977). Cross infection in a surgical ward caused by $P$ seudomonas aeruginosa with transferable resistance to gentamicin and tobramycin. Journal of Clinical Pathology 33, 731-736.

JACOBY, G. A. (1974). Property of R plasmids 
determining gentamicin resistance by acetylation in Pseudomonas aeruginosa. Antimicrobial Agents and Chemotherapy 6, 239-252.

KawaKami, Y., Mikoshiba, F., Nagasaki, S., MatsuOMOTO, H. \& TAZAKI, T. (1972). Prevalence of Pseudomonas aeruginosa strains possessing $\mathrm{R}$ factor in a hospital. Journal of Antibiotics 25, 607-609.

KorfHagen, T. R. \& Loper, J. C. (1975). RPL11, an $\mathrm{R}$ factor of Pseudomonas aeruginosa determining carbenicillin and gentamicin resistance. Antimicrobial Agents and Chemotherapy 7, 69-73.

KRISHNAPILlaI, V. (1975). Resistance to ultraviolet light and enhanced mutagenesis conferred by Pseudomonas aeruginosa plasmids. Mutation Research 29, 363-372.

KunG, A. H. C. \& LeE, B. T. O. (1973). The isolation and survival characteristics of radiation and chemical mutagen sensitive mutants of Pseudomonas aeruginosa. Mutation Research 20, 175-190.

Lehrbach, P., Kung, A. H. C. \& Lee, B. T. O. (1976). Mutants of Pseudomonas aeruginosa deficient in DNA polymerase I. Mutation Research 41, 391-394.

Lehrbach, P., Kung, A. H. C., Lee, B. T. O. \& JACOBY, G. A. (1977a). Plasmid modification of radiation and chemical-mutagen sensitivity in Pseudomonas aeruginosa. Journal of General Microbiology 98, 167-176.

Lehrbach, P., Kung, A. H. C. \& Lee, B. T. O. $(1977 b)$. Loss of ultraviolet light protection and enhanced ultraviolet light-induced mutability in Pseudomonas aeruginosa carrying mutant $\mathrm{R}$ plasmids. Journal of General Microbiology 101, 135-141.

Rossman, T., Meyn, M.S. \& Troll, W. (1975). Effects of sodium arsenite on the survival of UVirradiated Escherichia coli: inhibition of a recAdependent function. Mutation Research 30, 157162.

Rossman, T. G., Meyn, M. S. \& Troll, W. (1977). Effects of arsenite on DNA repair in Escherichia coli. Environmental Health Perspectives (in the Press).

TsenG, J. T. \& BRyan, L. E. (1973). Mechanisms of $\mathrm{R}$ factor $\mathrm{R} 931$ and chromosomal tetracycline resistance in Pseudomonas aeruginosa. Antimicrobial Agents and Chemotherapy 3, 638-641.

WITKIN, E. M. (1976). Ultraviolet mutagenesis and inducible DNA repair in Escherichia coli. Bacteriological Reviews 40, 869-907. 